\title{
AUGALINĖS KILMĖS ALIEJŲ, NAUDOJAMŲ PUSIAU KIETŲ VAISTU FORMU GAMYBOJE LIETUVOS VAISTINĖSE, ASORTIMENTO TYRIMAS
}

\author{
Edita Kizevičienè $\dot{e}^{1,2}$, Laimutė Jonaitienè ${ }^{2}$, Jurgita Daukšiené $\dot{1}^{1}$ Eglè Dieninyte் \\ Rimantas Pečiūra ${ }^{1}$ \\ ${ }^{1}$ Lietuvos sveikatos mokslu universiteto Medicinos akademijos Farmacijos fakultetas, \\ ${ }^{2}$ Kauno kolegijos Medicinos fakultetas
}

Raktažodžiai: augaliniai aliejai, pusiau kieta vaistų forma, ekstemporalūs vaistai.

\begin{abstract}
Santrauka
Didelę dalį vaistineje gaminamų vaistų sudaro pusiau kietos vaistų formos. Pusiau kieta vaisto forma yra greitai pagaminama, lengvai taikoma ir geba lokaliai pristatyti platų spektrą vaistų molekulių. Šio straipsnio autoriai atliko tyrimą tikslu nustatyti asortimentą augalinių aliejų, naudojamų pusiau kietų vaistų formų gamyboje Lietuvos vaistinèse. Atliekant tyrimą, taikyti metodai: mokslo šaltinių, profesinès literatūros analizè, apklausa telefonu, pateikiant respondentams klausimus pagal iš anksto sudarytą uždaro tipo klausimų apklausos anketą. Tyrimui pasirinkta 35 vaistinès, kurios turejjo licencijas vaistų gamybai, jose buvo gaminamos įvairios pusiau kietos vaistų formos. Analizuota mokslo ir profesinès literatūros šaltiniai - žinynai, kuriuose pateikiama informacija apie 346 Lietuvos vaistinèse gaminamus vaistus pagal gydytojų išrašytus receptus. Nustatyta, kad iki 2014 metu pagal pateiktus receptus vaistinès galèjo gaminti septyniasdešimt vieno pavadinimo (21\% visų pateiktų žinynuose receptų) įvairiems sveikatos sutrikimams gydyti ekstemporalius vaistus, $\mathfrak{i}$ kurių sudèti ịeina lipofilinès medžiagos: augaliniai, mineraliniai aliejai, gyvulinès kilmès riebalai.

Lietuvos vaistinèse gaminamos pusiau kietos vaistu formos - tepalai, linimentai, kremai ir geliai, kurių gamybai yra naudojami alyvuogių, saulègrąžų, ricinų ir migdolų aliejai. Alyvuogių aliejų pusiau kietų formų vaistų gamyboje dažniausiai vartoja $88,6 \%$, saulègrąžų aliejų - 80,0\%, ricinų aliejų $-65,7 \%$, migdolų aliejų $-22,9 \%$ apklaustujų vaistinių.
\end{abstract}

\section{Ivadas}

Didelę dalị vaistinejje gaminamų vaistų sudaro pusiau kietos vaistų formos. Jos naudojamos odos drékinimui arba tarnauja kaip vaistų nešikliai, kurie vaistus lokaliai pristato odai, ragenai, tiesiosios žarnos audiniams, nosies gleivinei, makščiai, burnos audiniams, šlaplès membranai ir išoriniam ausies pamušalui $[1,2]$, jų nenuplaunant, gali laikytis prisirišusios prie paviršiaus pakankamai ilgą laiką, tarnauti kaip pailginto veikimo vaistai $[1,3]$. Pusiau kieta vaisto forma yra greitai pagaminama, lengvai taikoma ir geba lokaliai pristatyti platų spektrą vaistų molekulių. Pusiau kietoms vaistu formoms priskiriama tepalai, kremai, geliai, pastos, kurių kiekviena išvardinta grupe pasižymi unikaliomis savybèmis $[4,5]$. Tepalai skirti išoriniam vartojimui - odai ar gleivinei, tepant juos ant odos, žaizdų ar gleivinès, kaip jas apsaugantys ir minkštinantys agentai arba kaip itterpiamų vaistų transporto priemonès. Tai optimaliausios vaistu formos, kuriose galima derinti skirtingos cheminès prigimties, agregatinès būsenos, įvairios paskirties ir biologinio aktyvumo komponentus, nes klampioje aplinkoje fizikiniai - cheminiai procesai vyksta lètai [6]. Geliai - pue siau kietos sistemos, sudarytos iš mažų kaip suspensijose neorganinių dalelių ar didelių organinių molekulių, ịsiskverbusių skystyje. Gelių pagrindas gali būti arba vanduo (vandeniniai geliai), arba organiniai tirpikliai - (organogeliai) [7] . Kremai - tai vandeniu nuplaunamos, kosmetiniu ir estetiniu požiūriu priimtinos pusiau kietos vaistų formos. Jų sudėtyje yra viena ar daugiau vaistinių medžiagų, ištirpinamų dažniausiai a/v tipo arba disperguotų mikrokristalinės ilgos grandinės riebalų rūgščiu ar alkoholių v/a tipo dvifazèse arba daugiafazèse dispersinių sistemų emulsijose [8]. Kremai plačiai naudojami farmacijoje ir kosmetis koje. Kosmetikoje riebioji lipofilinè fazė turi keletą tikslų - tarnauti priemoneje kaip emolientas arba kaip aktyvioji medžiaga. Emolientai, tai medžiagos, kurios prasiskverbia 
per ragini sluoksnį, tačiau neturi poveikio gilesniems odos sluoksniams. Jos minkština odą, gerina jos išvaizdą, glotnumą, stangrumą, bet neturi fiziologinio poveikio [9]. Odą minkštinančiais junginiais gali būti ir natūralūs riebalai, riebalų alkoholiai, lanolinas, tam tikri silikoniniai junginiai (silikono aliejus). Šiuolaikinèse kosmetinèse priemonèse kaip emolientus vis dažniau naudoja silikono aliejų, paliekant natūraliems riebalams, aliejams aktyvių priedų vaidmenị. Farmacines a/v tipo emulsijas paprastai sudaro aliejus arba riebalai ir vanduo. Aliejai, ęeinantys ị pusiau kietų vaistų formų - emulsinių kremų sudèti, daugiausia tarnauja kaip nešikliai - veikliosios medžiagos skverbties per odą stiprikliai, užtikrinantys šios medžiagos prasiskverbimą per odą ar gleivinę $[10,11]$. Cheminių medžiagų skverbties per odą stiprikliai keičia odos raginio sluoksnio barjero savybes ir tokiu būdu padidina vaistų pralaidumą visoje odoje. Skverbties stipriklio poveikis odai turètų būti grịžtamas, netoksiškas, nedirginantis odos, nealergiškas, suderinamas su vaistais ir pagalbinemis vaistų gamybos medžiagomis. İvairūs augalinès kilmès aliejai išlaiko saugaus ant odos vartojimo savybes. Manoma, kad natūralūs aliejai

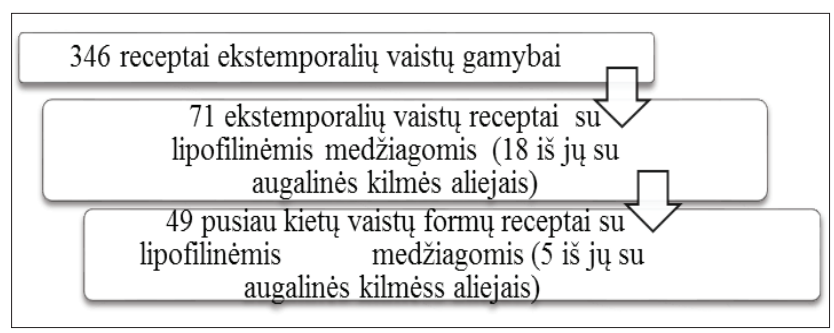

1 paveikslas. Pusiau kietų vaistų formų su augalinės kilmès aliejais gamybos receptų vieta literatūroje nurodytuose ekstemporalių vaistų gamybos receptūrų žinynuose

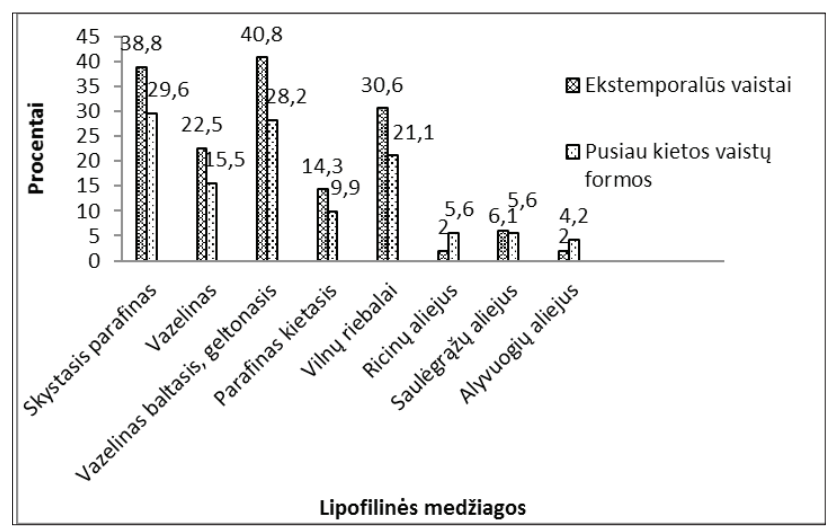

2 paveikslas. Lipofilinių medžiagų( $\%$ )naudojimas Lietuvos vaistinėse ekstemporalių vaistų ir pusiau kietų vaistų formų ( tepalų, kremų, pastų) gamyboje pagal gydytojų išrašytus receptus yra metabolizuojami odoje, išsiskiriant sočioms ir nesočioms riebalų rūgštims, kurios didina medžiagų skverbtị per odą. Šios riebalų rūgštys didina odos pralaidumą dėl lipidų plastų skystejjimo stratum corneum sluoksnyje ir gali veiksmingai pagerinti transderminį vaistų pernešimą [12]. Atliktų tyrimų su alyvuogių aliejumi rezultatai rodo, kad labiausiai skverbti per odą didina oleino, omega-6 ir kitos nesočios riebalų rūgštys [13]. Alyvuogių aliejuje yra oleino, linolo, linoleno rūgščių, iš kurių stipriomis skverbties per odą savybèmis pasižymi oleino rūgštis [14]. Kituose natūraliuose aliejuose - rapsų, saulègrąžų, žemès riešutų, pistacijų, migdolų, taip pat yra oleino rūgšties. Šie aliejai galètų didinti medžiagų skverbti per odą ir prisidèti prie natūralių augalinių aliejų asortimento plètros, tobulinant pusiau kietų vaistų formų kompozicijų panaudojimą vaistaims per odą pernešti.

Šio darbo tikslas: nustatyti augalinių aliejų, naudojamų pusiau kietų vaistų formų gamyboje Lietuvos vaistinèse, asortimentą.

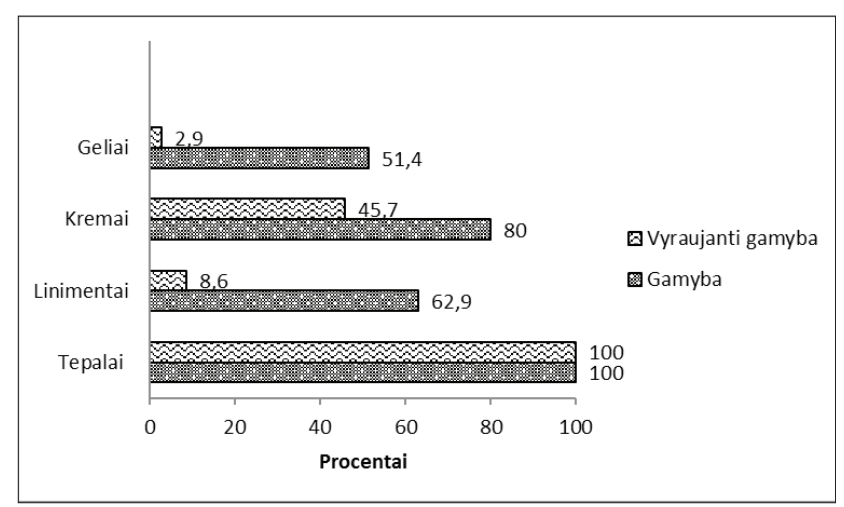

3 paveikslas. Pusiau kietų formų vaistų gamyba Lietuvos vaistinèse

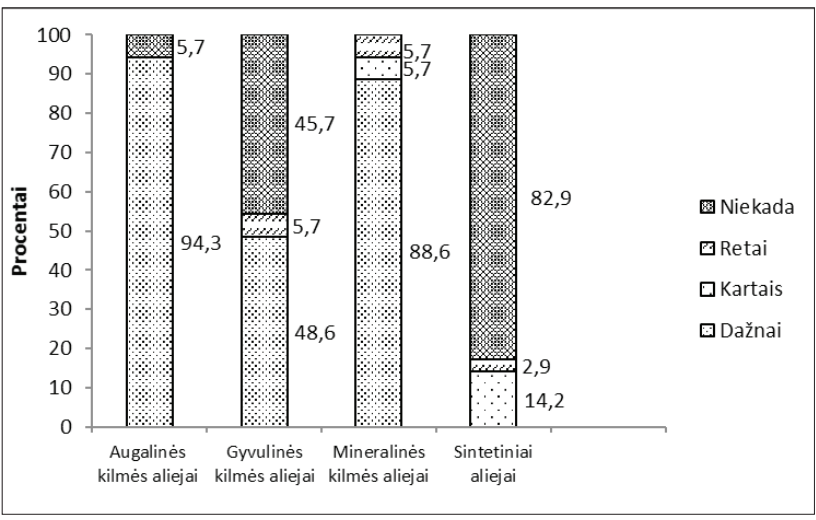

4 paveikslas. Lipofilinès medžiagos, vartojamos pusiau kietų vaistų formoms gaminti Lietuvos vaistinèse 


\section{Tyrimo objektas ir metodai}

Tirtas augalinès kilmės aliejų, naudojamų pusiau kietų formų ekstemporalių vaistų gamyboje, asortimentas. Atliekant tyrimą taikyti metodai: mokslo ir profesinès literatūros šaltinių analizè, apklausa telefonu, pagal iš anksto parengtą klausimyną. Gauti tyrimo rezultatai statistiškai apdoroti naudojant statistinius duomenų analizès paketus SPSS 20, Microsoft Office Excel 2007, programinès įrangos paketą „Prizma v.5.04“ (GraphPad Software Inc, La Jolla, Kalifornija).

Parenkant tyrimo apklausos imties dydi, buvo nustatyta, kad 2015 metais Lietuvoje veiklą vykdè 213 vaistinių ir 1174 jų filialai. Iš jų 36 visuomenès vaistinès, 26 jų filialai ir 25 ligoninès vaistinès ir 1 filialas turèjo licencijas vaistų gamybai ir gamino vaistus [15]. Tyrimui pasirinkta vaistinès, kurios turejo licencijas vaistu gamybai, jose buvo gaminamos įvairios pusiau kietos vaistų formos. Atrinktos 35 realiai vaistus gaminančios vaistinès ar jų filialai, atitinkančios pasirinktus kriterijus [16]. Paskambinus telefonu visų atrinktų vaistinių vadovams, gavus jų sutikimą, buvo vykdoma apklausa, pateikiant iš anksto parengtos anketos klausimus.

Respondentams buvo pateikiami klausimai pagal autorių sudarytą uždaro tipo klausimų anketą. Pirmieji du anketos klausimai skirti nustatyti, kokios pusiau kietos vaistų formos ir kurios iš jų dažniausiai yra gaminamos vaistineje[17]. Trečiuoju ir ketvirtuoju klausimais siekta išsiaiškinti lipofilinių medžiagų, augalinių aliejų įvairovę

1 lentelè. Sveikatos sutrikimai gydomi pagamintais vaistinèje pusiau kietų formų vaistais

*1-kasdien, 2 - kas savaitę, 3 -kas mènesi, 4-rečiau, negu kas mènesị, 5 niekada

\begin{tabular}{|l|l|c|c|c|c|}
\hline $\begin{array}{l}\text { Eil. } \\
\text { Nr. }\end{array}$ & $\begin{array}{l}\text { Sveikatos } \\
\text { sutrikimai }\end{array}$ & Moda & $\begin{array}{c}\text { Standartinis } \\
\text { nuokrypis }\end{array}$ & $\begin{array}{c}\text { Maksi- } \\
\text { mumas }\end{array}$ & $\begin{array}{c}\text { Mini- } \\
\text { mumas }\end{array}$ \\
\hline 1 & $\begin{array}{l}\text { Odos pro- } \\
\text { blemos }\end{array}$ & 1 & 1,083 & 1 & 5 \\
\hline $\mathbf{2}$ & $\begin{array}{l}\text { Reumatiniai } \\
\text { sutrikimai }\end{array}$ & 5 & 1,579 & 1 & 5 \\
\hline $\mathbf{3}$ & $\begin{array}{l}\text { Peršalimo } \\
\text { ligos }\end{array}$ & 5 & 1,183 & 1 & 5 \\
\hline $\mathbf{4}$ & $\begin{array}{l}\text { Burnos } \\
\text { gleivinès ir } \\
\text { gerklès prie- } \\
\text { žiūra }\end{array}$ & 5 & 1,303 & 1 & 5 \\
\hline $\mathbf{5}$ & $\begin{array}{l}\text { Viršutiniu } \\
\text { kvėpavimo } \\
\text { takų ligos }\end{array}$ & 5 & 1,636 & 1 & 5 \\
\hline $\mathbf{6}$ & Akių ligos & 5 & 0,979 & 1 & 5 \\
\hline $\mathbf{7}$ & Ausų ligos & 5 & 0,684 & 2 & 5 \\
\hline $\mathbf{8}$ & $\begin{array}{l}\text { Ginekologi- } \\
\text { nės ligos }\end{array}$ & 5 & 0,974 & 3 & 5 \\
\hline
\end{tabular}

gaminamuose pusiau kietos formos vaistuose. Penktuoju ir šeštuoju anketos klausimais siekta išryškinti, kokiu tikslu, profilaktikai ar terapijai, dažniausiai naudojamos gaminamos pusiau kietos vaistų formos ir nustatyti, kokiems sveikatos sutrikimams gydyti/naudoti profilaktiškai jos skirtos.

\section{Rezultatai ir jų aptarimas}

Analizuota profesinès literatūros šaltiniai - žinynai, kuriuose pateikiama informacija apie Lietuvos vaistinèse gaminamus 346 vaistus, išrašytus pagal gydytojų receptus $[17,18]$ (1 pav.).

Nustatyta, kad iki 2014 metu pagal pateiktus receptus vaistinès galëjo gaminti septyniasdešimt vieno pavadinimo (21\% visų pateiktų žinynuose receptų) įvairiems sveikatos sutrikimams gydyti ekstemporalius vaistus su lipofilinèmis medžiagomis: augaliniais, mineraliniais aliejais, gyvulinès kilmès riebalais. $69 \%$ šių receptų skirti pusiau kietų vaistų formų gamybai (1 pav.).

Pagal gydytojų išrašytus receptus Lietuvos vaistinėse buvo galima gaminti pusiau kietas vaistų formas - tepalus, linimentus, kremus ir gelius, kurių receptu sudètyje dominavo mineraliniai aliejai - kietasis parafinas, baltasis ir geltonasis parafinai, vazelinas ir vilnų riebalai (lanolinas) (2 pav.).

Aštuoniolikoje žinynuose pateiktų receptų minimi augalinės kilmės aliejai: sẻmenų, saulėgrąžų, alyvuogių, ricinų aliejai ir kakavos sviestas, iš jų ricinų aliejus minimas - keturiuose, kakavos sviestas - šešiuose, alyvuogių aliejus - trijuose, saulègrąžų aliejus - keturiuose receptuose, linų aliejus - viename recepte. Natūraliųjų aliejų asortimentas dar labiau susitraukia pusiau kietų vaistų formų keturiasdešimt devyniuose receptuose. Analizuojant šiuos receptus, išryškèja, kad augalinès kilmès aliejai įeina ị penkių receptų sudètị: alyvuogių ir ricinų aliejai minimi dviejuose receptuose, saulègrąžų aliejus įeina ị trijų receptų sudètį. Kakavos sviesto ir sėmenų aliejaus pateiktuose žinynų receptuose neliko (1, 2 pav.).

Tyrimas parodè, kad šiuo metu tyrime dalyvavusiose vaistinèse yra gaminamos pusiau kietos vaistu formos - tepalai, linimentai, kremai ir geliai: tepalai gaminami visose vaistinėse, daugumoje vaistinių gaminami kremai, pusejje iš jų - geliai, linimentai. Iš visų minètų pusiau kietų vaistų formų vyraujanti yra tepalų gamyba, jie dažniausiai gaminami visose apklaustose vaistinėse. Kremai dažniausiai gaminami beveik pusėje apklaustų vaistinių (45,7\%) (3 pav.).

Vaistinių vedèjai nurodè, kad gaminamos pusiau kietos vaistų formos yra vartojamos įvairiems sveikatos sutrikimams gydyti (1 lentelè).

Lentelèje pateikti duomenys leidžia teigti, kad Lietuvos vaistinėse dažniausiai gaminami tepalai ir kremai yra 


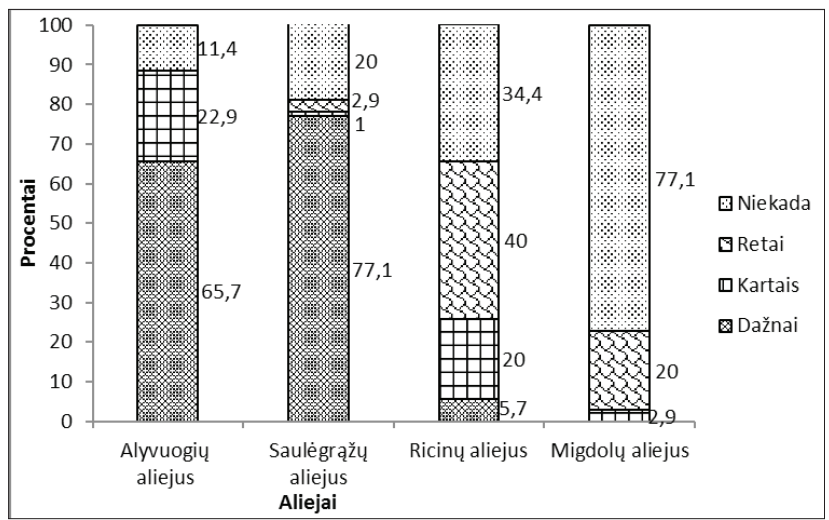

5 paveikslas. Augalinès kilmès aliejai, vartojami pusiau kietų vaistų formoms gaminti Lietuvos vaistinèse

vartojami odos problemoms spręsti (60\% vaistinèse juos gamina kasdien, 28,6\% kartą per savaitę). Rečiau vaistinèse gaminamos pusiau kietos vaistų formos visiems kitiems nurodytiems sveikatos sutrikimams spręsti: viršutinių kvèpavimo takų ligoms gydyti (kasdien gaminama - 20\%, kas savaitę $-22,9 \%$ vaistinèse), reumatiniams sutrikimams gydyti - kasdien gamina 20\%, kas savaitę - 5,7\% vaistinèse, burnos gleivinès ir gerklès priežiūrai kasdien gamina 5,7\%, kas savaitę - 11,4\% vaistinèse. Labai retai vaistinèse gaminamos pusiau kietos vaistų formos peršalimo, akių, ausų ir ginekologinèms ligoms gydyti.

Pusiau kietoms vaistu formoms gaminti yra vartojamos ịvairios lipofilinès medžiagos - augalinès ir gyvulinès kilmès aliejai, riebalai ir vaškai, mineraliniai ir sintetiniai aliejai. Dažnai gamyboje yra vartojami augalinès kilmès aliejai, rečiau - mineralinès kilmès, sintetiniai aliejai beveik nevartojami (4 pav.).

Pusiau kietų vaistų formų gamyboje populiariausias iš augalinės kilmės aliejų yra alyvuogių aliejus, kurị dažnai ir kartais vartoja 88,6\% apklaustų vaistinių. Saulėgrąžų aliejų dažnai ir kartais vartoja 80,0\%, ricinų aliejų - 65,7\%, migdolų aliejų - 22,9\% apklaustų vaistinių ( 5 pav.).

\section{Išvados}

1. Lietuvos vaistinėse gaminamų vaistų receptūrų žinynų analizė parodè, kad augalinės kilmės saulègrąžų, alyvuogių, ricinų aliejai ịeina ị pusiau kietos formos vaistų receptų sudètị. Daugumoje receptų kaip lipofilinès medžiagos yra minimi mineraliniai aliejai - kietasis parafinas, baltasis ir geltonasis vazelinai, vazelinas, skystasis parafinas ir vilnų riebalai.

2. Pusiau kietoms vaistų formoms gaminti yra naudojamos ịvairios lipofilinès medžiagos - augalinès ir gyvulinès kilmès aliejai, riebalai ir vaškai, mineraliniai ir sintetiniai aliejai. Dažniausiai gamyboje yra naudojami augalinès kilmès aliejai, rečiau - mineralinès kilmès, sintetiniai aliejai beveik nenaudojami. Pusiau kietų vaistu formų gamyboje populiariausias iš augalinès kilmès aliejų yra alyvuogių aliejus, kurị naudoja 88,6\% apklaustų vaistinių. Saulègrąžų aliejų naudoja $80,0 \%$, ricinų aliejų - 65,7\%, migdolų aliejų - 22,9\% apklaustujų vaistinių.

3. Šiuo metu Lietuvos vaistinèse yra gaminamos pusiau kietos vaistu formos - tepalai, linimentai, kremai ir geliai. Visose tyrime dalyvavusiose vaistinèse yra gaminami tepalai, daugelyje vaistiniu (80\%) gaminami kremai. Pusiau kietos vaistų formos, pagamintos vaistinèse, yra naudojamos odos problemoms spręsti (60\% vaistinių jas gaminama kasdien, 28,6\% kartą per savaitę).

\section{Literatūra}

1. Jeong CB, Han JY, Cho JC, Suh KD, Nam GW. Analysis of electrical property changes of skin by oil-in-water emulsion components. International Journal of Cosmetic Science 2013;35(4):402-10.

http://dx.doi.org/10.1111/ics.12059

2. Buhse L, Kolinski R, Westenberger B, Wokovich A, Spencer J, Chen CW. et al. Topical drug classification. International Journal Of Pharmaceutics 2005;295(1-2):101-12.

http://dx.doi.org/10.1016/j.ijpharm.2005.01.032

3. Gupta P, Garg S. Semisolid dosage forms for dermatological application. Pharmaceutical technology 2002;144-62.Prieiga per internetą: < http://images.alfresco.advanstar.com/alfresco_images/pharma/2014/08/22/291f251d-dbf9-46a7-9463c330a5e0cb7c/article-12404.pdf >, [žiūrèta 201608 12].

4. Maitri S, Modi D, Shah D. A new future approach in novel drug delivery system through micro-emulge;: review World Journal of Pharmacy and Pharmaceutical Sciences 2016;5(5):243-59.

5. Purushottam S, Bhaskarrao G, Ravindra S. Gellified emulsion: a new born formulation for topical delivery of hydrophobic drugs. World Journal of Pharmacy and Pharmaceutical Sciences 2013;3:233-51.

6. Singh Malik D, Mital N, Kaur G. Topical drug delivery systems: a patent review. Expert opinion on therapeutic patents 2016;26(2):213-28. http://dx.doi.org/10.1517/13543776.2016.1131267

7. Rehman K, Zulfakar MH. Recent advances in gel technologies for topical and transdermal drug delivery. Drug development and industrial pharmacy 2014;40(4):433-40. http://dx.doi.org/10.3109/03639045.2013.828219

8. Garg T, Rath G, Goyal AK. Comprehensive review on additives of topical dosage forms for drug delivery. Drug Delivery 2015;22(8):969-87. http://dx.doi.org/10.3109/10717544.2013.879355

9. Otto A, Du Plessis J, Wiechers J. Formulation effects of topical emulsions on transdermal and dermal delivery. International 
journal of cosmetic science. 2009;31(1):1-19. http://dx.doi.org/10.1111/j.1468-2494.2008.00467.x

10. Williams AC, Barry BW. Penetration enhancers. Advanced Drug Delivery Reviews. 2012;64 Supplement:128-37. http://dx.doi.org/10.1016/j.addr.2012.09.032

11. Puglia C, Bonina F. Effect of polyunsaturated fatty acids and some conventional penetration enhancers on transdermal delivery of atenolol. Drug delivery 2008;15(2):107-12. http://dx.doi.org/10.1080/10717540801905090

12. Zadymova NM. Colloidochemical aspects of transdermal drug delivery (review). Colloid Journal 2013;75(5):491-503. http://dx.doi.org/10.1134/S1061933X13050189

13. Viljoen JM, Cowley A, Du Preez J, Gerber M, Du Plessis J. Penetration enhancing effects of selected natural oils utilized in topical dosage forms. Drug development and industrial pharmacy 2015;41(12):2045-54. http://dx.doi.org/10.3109/03639045.2015.1047847

14. Clodoveo ML, Camposeo S, De Gennaro B, Pascuzzi S, Roselli L. In the ancient world, virgin olive oil was called "liquid gold" by Homer and "the great healer" by Hippocrates. Why has this mythic image been forgotten? Food Research International 2014;62:1062-8.

http://dx.doi.org/10.1016/j.foodres.2014.05.034

15. Licencijuotos farmacijos įmonès (Narkotikai ir psichotropai) (sąrašas - 2015-12-31). Valstybinė vaistų kontrolès tarnyba prie Lietuvos Respublikos Sveikatos apsaugos ministerijos . Prieiga per internetą: <http://www.vvkt.lt/Farmacine-licencijuojamaveikla>, [žiūrèta 201607 22].

16. Grincevičiūtè N., Grincevičienè Š., Grincevičius J. Ekstemporalūs vaistai. Didžiųjų Lietuvos miestų vaistinių vadovų nuomonè. Lietuvos bendrosios praktikos gydytojas, 2012; 06.

17. Savickas A. KG, Ramanauskienė K., Kalvėnienė Z. Trumpas Lietuvos vaistinèse gaminamų vaistų receptūrų žinynas. LSMU leidykla, 2014.

18. Ramanauskienè K. S.A., Švambaris L.K. Lietuvos vaistinėse gaminamų vaistų receptūrų žinynas. LSMU leidykla, 2005; 3-143.

INVESTIGATION OF THE RANGE OF VEGETABLE OILS, USED IN THE PRODUCTION OF SEMI-SOLID
PHARMACEUTICAL FORMULATIONS, IN LITHUANIAN PHARMACIES

\section{E. Kizevičienė, L. Jonaitienè, J. Daukšienė, E. Dieninytė,}

\section{R. Pečiūra}

Key words: vegetable oils, semi-solid pharmaceutical formulations, extemporaneus drugs.

Summary

A large part of medications produced in the pharmacy consist of semi-solid formulations. Semi-solid formulation of medications is quickly produced, easily applied, and is able to deliver a wide range of pharmaceutical molecules locally. The authors of this paper have conducted the research with the aim to identify the range of vegetable oils, used in the production of semi-solid pharmaceutical formulations, in Lithuanian pharmacies. The following methods were used to perfrom the investigation: analysis of scientific sources and professional literature, telephone survey, presenting respondents a previously developed questionnaire survey containing closed type questions. The principle of a snowball was selected. The following scientific references and professional literature were analyzed - reference books containing information about 346 medicines on doctor's prescription produced in the pharmacies in Lithuania. The research revealed that by the year 2014 in accordance with the doctor's prescription pharmacies could produce extemporaneous medicines of seventy-one title ( $21 \%$ of all the presented in manuals) for various health disorders, containing lipophilic substances: vegetable, mineral oils, animal fats. Some formulations contain several lipophilic substances. The following semi-solid pharmaceutical formulations are produced in Lithuanian pharmacies - ointments, liniments, creams and gels, for the production of which olive, sunflower, castor and almond oils are used. For the production of semi-solid pharmaceutical formulations $88,6 \%$, of surveyed pharmacies use olive oil, $80,0 \%$ of pharmacies use sunflower oil, $65,7 \%$-castor oil and $22,9 \%$ of pharmacies use almond oil.

Correspondence to: laimute.jonaitiene@go.kauko.lt

Gauta 2016-09-30 